\title{
Factors associated with social responsibility among university students in Yala, Thailand during the COVID-19 pandemic
}

\author{
Awirut Singkun
Sirindhorn College of Public Health, Yala, \\ Awirut Singkun
Sirindhorn College of Public Health, Yala, \\ Faculty of Public Health Sciences and Allied Health Sciences, \\ Praboromarajchanok Institute, Muang Yala, Thailand
}

\begin{abstract}
Purpose - The objectives of this study were to evaluate knowledge on the coronavirus disease 2019 (COVID-19) transmission, attitude toward the measures of COVID-19 prevention and control, explore social responsibility behaviors and test for the association between variables and social responsibility among university students.

Design/methodology/approach - It was a cross-sectional study. The population was 7,754 students from a university in Yala province. The sample size was 370 students according to Krejcie and Morgan table. Google form was introduced to make the self-administered questionnaires. Content validity was evaluated by three experts, and for reliability of knowledge and attitude, the coefficient was 0.707 and 0.702 . Data collection was done in the early April 2020. Descriptive statistics and $\chi^{2}$ were used to analyze the data. Ethical approval number 095-63.

Findings - The results found that students' knowledge on COVID-19 transmission was in a moderate level, attitude toward the state measures for COVID-19 prevention and control was at a high level. Their social responsibility behaviors were at a high level. Their knowledge, attitude and payment were significant association with social responsibility behaviors among university students $(p<0.05)$.

Originality/value - University students' knowledge on disease transmission as well as positive attitude toward the measures of regulation led them to have cooperation. Social distancing and lockdown measures affected their lifestyle. However, they have responsibility behaviors to the society, especially in the pandemic situation.
\end{abstract}

Keywords Coronavirus 2019, COVID-19, Pandemic, Social responsibility, Thailand

Paper type Research paper

\section{Introduction}

The first coronavirus disease 2019 (COVID-19) patient was diagnosed in China in November 2019 [1]. COVID-19 is a respiratory illness that can spread from person to person. The most reported symptoms were fever $83.0-98.8 \%$, cough $76.0-82.0 \%$ and shortness of breath 31.0 $63.5 \%[2-5]$.The symptoms of the disease are similar to the common cold or influenza. Infected patients may have difficulty in breathing, can develop pneumonia in more severe cases and the disease can be fatal. The median duration from onset of symptoms to radiological confirmation of pneumonia was about 5 days, and from the onset of symptoms to the intensive care unit was 9.5 days [2-4].

(C) Awirut Singkun. Published in the Journal of Health Research. Published by Emerald Publishing Limited. This article is published under the Creative Commons Attribution (CC BY 4.0) licence. Anyone may reproduce, distribute, translate and create derivative works of this article (for both commercial and non-commercial purposes), subject to full attribution to the original publication and authors. The full terms of this licence may be seen at http://creativecommons.org/licences/by/4.0/legalcode

Disclosure: The authors report no conflicts of interest concerning this study.

The author thanks to Sirindhorn College of Public Health, Yala for budget supporting and all participants in this study.

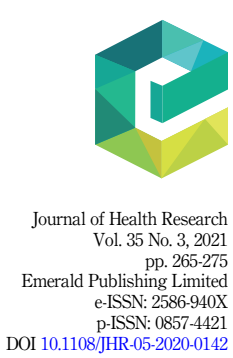


JHR

35,3

266
The disease has spread throughout 215 countries around the world. The confirmation of COVID-19 infection is 4,342,355 cases and 292,893 deaths [6]. In Thailand, COVID-19 is now listed as a dangerous communicable disease under the Communication Disease Act. The confirmation of COVID-19 infection is 3,017 cases, with 56 reported deaths, and there are 82,627 patients under investigation (PUI) cases [7]. In Yala province, Thailand, there are 133 cases and 2 recorded deaths [8].

Presently, there is no vaccine to induce antibody production. The evolving outbreak of COVID-19 now requires social distancing and other measures to protect public health $[9,10]$. The government of Thailand has correspondingly applied measures to prevent, suppress and delay the outbreak as well as to create awareness and understanding among the public. Regulations have been issued in the form of certain prohibitions and guidelines such as prohibitions from entering or leaving certain areas, prohibitions or limitations from entering or departing the kingdom and the movement of large numbers of people across various areas, the control of the use of vehicles, transportation routes and the control of goods and medical supplies [7].

COVID-19 is a concern for the individual, family, community and whole society where all members of the community must be aware of its rapid transmission rate [11]. The outbreak has reached a new peak and is a health risk that is increasing and speeding up the rate of sickness in the community [12].

In order to deal with the unprecedented level of emergency, it is important to develop a new mentality based on social responsibility. A sense of social responsibility will invariably align not only with the institutional and administrative voices but also support individual responses [13]. Social responsibility has emerged as a response to the increasing demand for society to be more responsible [14]. Spending time outdoors is good for our individual health, but social responsibility is essential for all our health. All members of society have to understand and practice measures for self-protection in order to ensure the prevention of COVID-19 transmission to others [10]. This requires personal awareness, understanding and a sense of responsibility for society. However, COVID-19 is a new and current public health problem with no study in Thailand relevant to students' responsibilities toward society during a pandemic of this scale. There is no Thai-based study to date that has researched the association between knowledge of this disease transmission, attitude on the control measures and social responsibility behaviors. This study is based on Bloom's taxonomy, knowledge and attitude used to understand individual's behaviors [15] as well as the consideration that a person's behavior corresponds to their attitudes to a situation [16]. This study was performed to explore university students' knowledge of COVID-19 transmission, attitude toward the measures of COVID-19 prevention and control, the extent of social responsibility and to find out the association between studied factors and their social responsibility behaviors.

\section{Methodology}

Study design

This study was a cross-sectional research survey.

\section{Study procedure}

The population of this study was university students from a university in Yala province; The university has four faculties. The researcher recruited participants from all four faculties in order to ensure fair representation across the study population. There were 7,754 students from 54 curriculums in four faculties. This study took place during the second semester of the academic year 2019 [17].

The sample size was 370 respondents (at least 367 university students according to the Krejcie and Morgan table at a population of 8,000 sample units) [18]. The purposive sampling was used to select the participants with the following inclusion criteria: 
Inclusion criteria:

(1) Full-time bachelor's degree students in the 2nd semester of the academic year 2019

(2) Have a smartphone and access to a Facebook and/or Line social media application.

(3) Consent to participate in this study (an informed consent form was provided during the 1st page of the Google form questionnaires).

The exclusion criteria were in complete questionnaires.

\section{Research tools}

Self-administered questionnaires were used to collect the data. There were four parts:

Part I: General information, seven items.

Part II: Knowledge of COVID-19 transmission, 13 items. Participants got 1 point for a correct answer and 0 points for an incorrect answer or not sure of the answer to each item. The knowledge score was divided into three levels: good, moderate and poor [19].

Knowledge was interpreted into three levels according to the class interval. There were good (10.5-13.0 points), moderate (7.8-10.4 points) and poor (lower than 7.8 points) levels.

Part III: Attitude toward the state measures for COVID-19 prevention and control, nine items. This part consisted of positive statements (no. 2, 3, 5, 8 and 9) and negative statements (no. 1, 4, 6 and 7). Each item had a five-point rating scale (strongly agree, agree, undecided, disagree and strongly disagree).

\begin{tabular}{lcc}
\hline Scoring & Positive statement & Negative statement \\
\hline Strongly agree & 5 & 1 \\
Agree & 4 & 2 \\
Undecided & 3 & 3 \\
Disagree & 2 & 4 \\
Strongly disagree & 1 & 5 \\
\hline
\end{tabular}

The attitude was interpreted into three levels (high: $33.0-45.0$ points; moderate: $21.0-32.9$ points and low: lower than 21.0 points) according to the class interval.

Part IV: Social responsibility behaviors, ten items. The positive behaviors were no. 1, 2, 3, 4, 5, 6, and 10 and the negative behaviors were no. 7, 8 and 9. This part assessed how frequently they practiced the points described in the first six questions, and daily for questions $7-10$.

\begin{tabular}{lcc}
\hline Scoring & Positive behaviour & Negative behavior \\
\hline Every time/Everyday & 5 & 1 \\
Always & 4 & 2 \\
Often & 3 & 3 \\
Sometimes & 2 & 4 \\
Have never done & 1 & 5 \\
\hline
\end{tabular}

The behaviors of social responsibility were interpreted into three levels (high: 36.7-50.0 points; moderate: 23.3-36.6 points and low: lower than 23.3) according to the class interval. 
JHR

35,3

\section{Tools measurement}

The assessment of content validity was evaluated by three experts in public health. The index of item-objective congruence (IOC) of each item of all parts was 1.00. Reliability was analyzed following a trial of 30 subjects from a university in Songkhla province. $\mathrm{KR}_{20}$ was used to analyze the reliability of knowledge on COVID-19 transmission, the coefficient was 0.707 and regarding attitude toward the state measures for COVID-19 prevention and control, Cronbach's $\alpha$ coefficient was used to analyze the data and was 0.702 .

\section{Data collection}

Data collection was performed in the first two weeks of April 2020. A set of questions were placed in a Google form. Messages on Facebook and Line applications were used to introduce data collection during the COVID-19 pandemic and the government announced the measures of social distancing for COVID-19 prevention and control. A link to the Google form questionnaires was initiated through the Facebook friends and Line friends of the researcher. The researcher asked them to distribute the link to their friends in the same university regardless of the year of study or faculty attended. Participants may have received the link more than once but were required to respond only once.

\section{Data analysis}

Descriptive statistics including frequency, percentage, mean, standard deviation, maximum and minimum were used to analyze the data. Chi-square was used to analyze the association between studied factors and social responsibility behaviors among university students.

\section{Ethical consideration}

Ethical consideration was approved by the Ethics Committee for Human Research Subjects of Sirindhorn College of Public Health, Yala (Project no. 095-63).

\section{Results}

Table 1 showed that most participants were female $(72.4 \%)$. Their average age was $20.70 \pm 1.64$ years, $78.4 \%$ of the participants were 20 years and older; and $80.8 \%$ practiced Islam. There were similar proportions of students in all four faculties. Approximately, $60.8 \%$ of the participants were in their first or second years of study. Almost half of them $(48.9 \%)$ stayed in their own house. Most of them $(82.7 \%)$ had a weekly income of less than 1,000 Baht.

Table 2 showed participants' knowledge of COVID-19 transmission. The three highest score responses recorded knowledge that COVID-19 can be transmitted at a higher rate in crowed places $(97.8 \%)$, that the risk of COVID-19 infection could be lowered when people wear a face mask $(96.5 \%)$ and that COVID-19 can be found in droplets when coughing or sneezing $(95.7 \%)$. Regarding incorrect answers, believing that COVID-19 can enter into the body through the skin on the palms (64.3\%), 20-40-year-old people are at a higher risk of COVID-19 infection than 75 year-olds $(61.9 \%)$, and COVID-19 patients will recover after they quarantine themselves for 14 days $(43.0 \%)$, respectively. Knowledge levels of COVID-19 transmission were at a moderate level of $52.4 \%$, as detailed in Table 5 .

Table 3 showed the attitude of university students toward the state measures for COVID19 prevention and control. Participants strongly agreed with the statement "All people must have responsibility for COVID-19 prevention and control" (85.9\%). They agreed that "Mass movement from one place to another area may increase the transmission of COVID-19" $(28.4 \%)$. For the statement of "Although we are concerned about COVID-19 prevention and control, religious activities or traditional culture should not be suspended," they were undecided (17.8\%) or disagreed (14.6\%). They strongly disagreed with "People should have a 


\begin{tabular}{|c|c|c|c|}
\hline General information & Frequency & $\%$ & $\begin{array}{r}\text { Factors } \\
\text { associated }\end{array}$ \\
\hline $\begin{array}{l}\text { Gender } \\
\text { Female } \\
\text { Male }\end{array}$ & $\begin{array}{l}268 \\
102\end{array}$ & $\begin{array}{l}72.4 \\
27.6\end{array}$ & $\begin{array}{l}\text { with social } \\
\text { responsibility }\end{array}$ \\
\hline $\begin{array}{l}\text { Age (mean: } 20.70 \text { years, SD: } 1.64 \\
\text { Lower than } 20 \text { years } \\
20 \text { years and upper }\end{array}$ & $\begin{array}{r}80 \\
290\end{array}$ & $\begin{array}{l}21.6 \\
78.4\end{array}$ & 269 \\
\hline $\begin{array}{l}\text { Religion } \\
\text { Islam } \\
\text { Buddhism }\end{array}$ & $\begin{array}{r}299 \\
71\end{array}$ & $\begin{array}{l}80.8 \\
19.2\end{array}$ & \\
\hline $\begin{array}{l}\text { Faculty } \\
\text { Humanities and social sciences } \\
\text { Education } \\
\text { Sciences and technologies } \\
\text { Management sciences }\end{array}$ & $\begin{array}{r}103 \\
90 \\
99 \\
78\end{array}$ & $\begin{array}{l}27.8 \\
24.3 \\
26.8 \\
21.1\end{array}$ & \\
\hline $\begin{array}{l}\text { Year level (year) } \\
\text { 1st } \\
\text { 2nd } \\
\text { 3rd } \\
4 \text { th } \\
5 \text { th }\end{array}$ & $\begin{array}{r}113 \\
112 \\
77 \\
65 \\
3\end{array}$ & $\begin{array}{r}30.5 \\
30.3 \\
20.8 \\
17.6 \\
0.8\end{array}$ & \\
\hline $\begin{array}{l}\text { Residence } \\
\text { Own house } \\
\text { College dormitory } \\
\text { Private dormitory }\end{array}$ & $\begin{array}{r}181 \\
98 \\
91\end{array}$ & $\begin{array}{l}48.9 \\
26.5 \\
24.6\end{array}$ & \\
\hline $\begin{array}{l}\text { Income per week (Baht) } \\
\leq 1,000 \\
>1,000\end{array}$ & $\begin{array}{r}306 \\
64\end{array}$ & $\begin{array}{l}82.7 \\
17.3\end{array}$ & $\begin{array}{r}\text { Table 1. } \\
\text { General } \\
\text { information }(n=370)\end{array}$ \\
\hline
\end{tabular}

party with their friends when they feel stress because of the COVID-19 pandemic" (57.8\%). About three-fourths of them had a high positive attitude toward the state measures for COVID-19 prevention and control (78.9\%), Table 5 .

The behavior questions related to university students' behaviors in the last two months. Their behaviors of social responsibility are shown in Table 4. High scores for "every time" were reported for "When you are in close contact with others, you wear a face mask" (73.0\%), "You must quarantine yourself when you go to or come back from other areas" $(71.9 \%)$, and "When you have close contact with people, you keep a distance of at least a meter from others" (54.1\%). Behaviors that were not practiced were "You have a party with your friends" (56.5\%), "You go to crowded areas or entertainment places" $(39.5 \%)$, and "You shake hands, touch others' body or things" $(31.6 \%)$, respectively. Participants' social responsibility behaviors were shown to be at a high level (66.5\%), Table 5.

Table 6 showed the association between factors and social responsibility behaviors. The results indicated that their weekly income, knowledge level of COVID-19 transmission and attitude level of the state measures for COVID-19 prevention and control were significantly associated with social responsibility behaviors among university students $(\phi<0.05)$. Gender, age, religion, faculty, year level and residence were not associated with participants' social responsibility behaviors. 
JHR

35,3

Statement

Correct

Incorrect

1. *Hand washing by cleansing soap cannot destroy COVID-19

Frequency

$(\%) \quad$ Frequency

$(\%)$

2. COVID-19 can be found in droplets when coughing or sneezing

214

534

(57.8)

156

$(42.2)$

3. The risk of COVID-19 infection can be lowered when people

357

(95.7)

16

wear face masks

\section{0}

4. COVID-19 stays alive on the surface of clothes and objects

5. People could be infected with COVID-19 despite wearing a face mask

6. Personal distancing could reduce the chance of COVID-19 infection

7. *Wearing a face mask cannot decrease COVID-19 when infected patients cough or sneeze

8. COVID-19 could enter the body through conjunctiva when people touch their eyes

9. Infected patients' clothes or belongings can transmit COVID-19 to other people

10. COVID-19 transmission is increased in crowded places

11. *COVID-19 patients will get well when they quarantine themselves for 14 days

12. *20-40 years old people have a higher risk of COVID-19

Table 2.

Knowledge of COVID-19

transmission $(n=370)$ infection than 75-year-olds

13. *COVID-19 can enter into the body through the skin on the palms $\begin{array}{llll}346 & (93.5) & 24 & (6.5)\end{array}$

$\begin{array}{llll}285 & (77.0) & 85 & (23.0)\end{array}$

$352 \quad(95.1) \quad 18 \quad(4.9)$

$222 \quad(60.0) \quad 148 \quad(40.0)$

$316 \quad(85.4) \quad 54 \quad(14.6)$

$\begin{array}{llll}336 & (90.8) \quad 34 & (9.2)\end{array}$

$\begin{array}{llll}362 & (97.8) & 8 & (2.2)\end{array}$

$211 \quad(57.0) \quad 159 \quad$ (43.0)

$141 \quad(38.1) \quad 229 \quad(61.9)$

$\begin{array}{llll}132 & (35.7) \quad 238 \quad(64.3)\end{array}$

Note(s): *Negative statements

\section{Discussion}

Knowledge of COVID-19 transmission and attitude toward the state measures for COVID-19 prevention and control were significantly associated with participants' social responsibility behaviors. The findings were consistent with the study of Zhong et al. [20] that people's cooperation in controlled measures is affected by their knowledge, attitudes and practices related to the disease. Social responsibility behaviors are behaviors that concern society. University students are accepted as being well-educated. Participants' behaviors regarding COVID-19 prevention rely on individual responsibility as well as social responsibility behaviors during the COVID-19 pandemic period. People should take the initiative regarding their own health and not depend on the government or health personnel[12]. People with good perceptions of social responsibility are influenced by their cooperative behaviors and this leads to cooperative participation and positive actions [21]. A healthy society can be built by health promotion, which must take place socially responsibly and holistically [22]. Social responsibility becomes a common practice across developed and developing countries depending on the socially sustainable health of stakeholders [23]. Furthermore, social responsibility does not require technology [22].

Knowledge levels among university students concerning COVID-19 transmission were at a moderate level (60.0-79.0\% of score), and $38.9 \%$ had above average knowledge levels. This finding was similar to a study by Wolf et al. [9] where participants identified symptoms $(71.7 \%)$ and behaviors of COVID-19 prevention (69.8\%). The efficiency of their knowledge on the disease could lead them to be well-prepared for the COVID-19 outbreak with less xenophobic responses within their university and reduced social stigma when someone presented with a specific illness of the respiratory tract [11].

Attitudes toward the state measures for COVID-19 prevention and control was at a high level and associated with socially responsible behaviors. This is similar to the findings of a 


\begin{tabular}{|c|c|c|c|c|c|c|}
\hline \multirow[b]{2}{*}{ Statement } & \multirow{2}{*}{$\begin{array}{l}\text { Strongly } \\
\text { agree }\end{array}$} & \multicolumn{3}{|c|}{ Attitude $n(\%)$} & \multirow{2}{*}{$\begin{array}{l}\text { Strongly } \\
\text { disagree }\end{array}$} & \multirow{2}{*}{$\begin{array}{r}\text { Factors } \\
\text { associated } \\
\text { with social } \\
\text { responsibility }\end{array}$} \\
\hline & & Agree & Undecided & Disagree & & \\
\hline $\begin{array}{l}\text { 1. *Quarantined persons at risk of COVID- } \\
19 \text { infection feel stigmatized }\end{array}$ & 44 (11.9) & 43 (11.6) & 42 (11.3) & $28(7.6)$ & $213(57.6)$ & \\
\hline $\begin{array}{l}\text { 2. One example of social responsibility } \\
\text { behaviors is protecting yourself from } \\
\text { COVID-19 infection }\end{array}$ & $299(80.8)$ & $60(16.2)$ & $8(2.2)$ & $1(0.3)$ & $2(0.5)$ & 271 \\
\hline $\begin{array}{l}\text { 3. All people must have responsibility for } \\
\text { COVID-19 prevention and control }\end{array}$ & 318 (85.9) & $39(10.5)$ & $11(3.0)$ & $1(0.3)$ & $1(0.3)$ & \\
\hline $\begin{array}{l}\text { 4. *Despite concern for COVID-19 } \\
\text { prevention and control, religious } \\
\text { activities or traditional culture should } \\
\text { not be suspended }\end{array}$ & 68 (18.4) & $36(9.7)$ & $66(17.8)$ & $54(14.6)$ & 146 (39.5) & \\
\hline $\begin{array}{l}\text { 5. Personal distancing is a measure to } \\
\text { reduce the risk of COVID-19 infection }\end{array}$ & 255 (68.9) & $88(23.8)$ & $21(5.7)$ & $2(0.5)$ & $4(1.1)$ & \\
\hline $\begin{array}{l}\text { 6. *People should have parties with their } \\
\text { friends when they feel stressed due to } \\
\text { the COVID-19 pandemic }\end{array}$ & $30(8.1)$ & $25(6.8)$ & $49(13.2)$ & $52(14.1)$ & $214(57.8)$ & \\
\hline $\begin{array}{l}\text { 7. *To avoid upset, you should not clean } \\
\text { your hands with soap after touching } \\
\text { another person's hand, body or } \\
\text { personal equipment }\end{array}$ & $26(7.1)$ & $33(8.9)$ & $50(13.5)$ & 53 (14.3) & $208(56.2)$ & \\
\hline $\begin{array}{l}\text { 8. Mass movement from one place to } \\
\text { another area may increase COVID-19 } \\
\text { transmission }\end{array}$ & $193(52.2)$ & $105(28.4)$ & $54(14.6)$ & $8(2.1)$ & $10(2.7)$ & \\
\hline $\begin{array}{l}\text { 9. New cases of COVID-19 infection will } \\
\text { reduce measures such as temporarily } \\
\text { closure of entertainment places or } \\
\text { crowded areas }\end{array}$ & 275 (74.3) & $63(17.0)$ & $29(7.9)$ & $1(0.3)$ & $2(0.5)$ & $\begin{array}{r}\text { Table 3. } \\
\text { Attitudes toward state } \\
\text { measures for COVID- } \\
19 \text { prevention and }\end{array}$ \\
\hline Note(s): *Negative statements & & & & & & control $(n=370)$ \\
\hline
\end{tabular}

previous study where a more positive attitude to something or events resulted in people being more cooperative [24]. In addition, attitude levels were consistent with the burden of the stage of communicable disease, especially, in the outbreak period [25]. People appreciate the value of being in good health and accept responsibility [12]. Another study found that a corporate social responsibility approach demonstrates people's ability to encourage meaningful social change and play an active role for the benefit of society [26]. Social responsibility occurs through helping to address global challenges on health and health promotion in the family, workplace and communities [23]. COVID-19 will be controlled by maintaining personal hygiene as well as avoiding unnecessary travel, avoiding any programs where people gather and by maintaining social distancing. These social aspects and responsibilities can break the chain of spreading the disease [5]. Social responsibility behaviors are seen as a complement to strong social regulation [27].

\section{Limitation}

This study did not calculate the proportion of the sample size of each faculty and there was a lack of random sampling. However, the sample size of the study was greater than the least sample size determination by the Krejcie and Morgan table. For further study, a simple random sampling technique should be used after being stratified by curriculum and faculty. 
JHR

35,3

\begin{tabular}{|c|c|c|c|c|c|}
\hline \multirow[b]{2}{*}{$\underline{\text { Statement }}$} & \multicolumn{5}{|c|}{ Frequency of behavior $n(\%)$} \\
\hline & or everyday & Always & Often & Sometimes & $\begin{array}{l}\text { ive never } \\
\text { done }\end{array}$ \\
\hline $\begin{array}{l}\text { 1. When you are in close contact with } \\
\text { others, you wear a face mask }\end{array}$ & $270(73.0)$ & $66(17.8)$ & $27(7.3)$ & $4(1.1)$ & $3(0.8)$ \\
\hline $\begin{array}{l}\text { 2. You clean public equipment with } \\
\text { disinfectants or alcohol spray after } \\
\text { you finish using it }\end{array}$ & $130(35.1)$ & $66(17.8)$ & $111(30.0)$ & $36(9.7)$ & $27(7.3)$ \\
\hline $\begin{array}{l}\text { 3. You must quarantine yourself when } \\
\text { you go to or come back from other } \\
\text { areas }\end{array}$ & 266 (71.9) & $31(8.4)$ & $31(8.4)$ & $21(5.7)$ & $21(5.7)$ \\
\hline $\begin{array}{l}\text { 4. When you must be in close contact } \\
\text { with people, you maintain a distance of } \\
\text { at least a meter from others }\end{array}$ & $200(54.1)$ & $86(23.2)$ & $62(16.8)$ & $16(4.3)$ & $6(1.6)$ \\
\hline $\begin{array}{l}\text { 5. You keep a distance of at least } 1 \mathrm{~m} \\
\text { from your close friends or family } \\
\text { members }\end{array}$ & $111(30.0)$ & $70(18.9)$ & $93(25.1)$ & $38(10.3)$ & $58(15.7)$ \\
\hline $\begin{array}{l}\text { 6. When you have a chance, you donate } \\
\text { money/things or provide help for } \\
\text { COVID-19 prevention and control }\end{array}$ & $116(31.3)$ & $65(17.6)$ & $114(30.8)$ & $41(11.1)$ & $34(9.2)$ \\
\hline 7. *You have a party with your friends & $48(13.0)$ & $16(4.3)$ & $45(12.2)$ & $52(14.0)$ & 209 (56.5) \\
\hline $\begin{array}{l}\text { 8. *You go to crowded areas or } \\
\text { entertainment places }\end{array}$ & $47(12.7)$ & $16(4.3)$ & $63(17.0)$ & $98(26.5)$ & $146(39.5)$ \\
\hline $\begin{array}{l}\text { 9. *You shake hands, touch others' body } \\
\text { or things }\end{array}$ & 49 (13.2) & $15(4.1)$ & $88(23.8)$ & $101(27.3)$ & $117(31.6)$ \\
\hline $\begin{array}{l}\text { 10. You give recommendations to others } \\
\text { about COVID-19 prevention and } \\
\text { control }\end{array}$ & 149 (40.3) & $81(21.9)$ & $119(32.2)$ & $14(3.8)$ & $7(1.9)$ \\
\hline Note(s): *Negative statements & & & & & \\
\hline
\end{tabular}

\section{Table 5.}

Knowledge level of COVID-19

transmission, attitude level of the state measures and social responsibility behaviors level $(n=370)$

\begin{tabular}{lccc}
\hline Level & Knowledge level & $\begin{array}{c}\text { Frequency (\%) } \\
\text { Attitude level }\end{array}$ & Behavior level \\
\hline Good/High & $144(38.9)$ & $292(78.9)$ & $246(66.5)$ \\
Moderate & $194(52.4)$ & $78(21.1)$ & $124(33.5)$ \\
Poor/Low & $32(8.7)$ & - & - \\
\hline
\end{tabular}

\section{Conclusion}

University students' knowledge of COVID-19 transmission is at a moderate level (52.4\%), their attitude toward the state measures for COVID-19 prevention and control was at a high level $(78.9 \%)$, and their behaviors of social responsibility were at a high level $(66.5 \%)$. The association between studied factors and social responsibility behaviors found that weekly income, knowledge of COVID-19 transmission and attitude toward the state measures for COVID-19 prevention and control were significantly associated with social responsibility behaviors among university students $(p<0.05)$. Based on the results of this research, social responsibility should be integrated into the learning system in order to fulfill students' skills and performance. 


\begin{tabular}{|c|c|c|c|c|c|c|c|c|}
\hline \multirow{3}{*}{$\frac{\text { Variable }}{\text { Gender }}$} & \multicolumn{4}{|c|}{$\begin{array}{l}\text { Social responsibility } \\
\text { behavior level } n(\%)\end{array}$} & \multirow[b]{2}{*}{$x^{2}$} & \multirow[b]{2}{*}{ df } & \multirow[b]{2}{*}{$p$-value } & \multirow{2}{*}{$\begin{array}{r}\text { Factors } \\
\text { associated } \\
\text { with social }\end{array}$} \\
\hline & & igh & & erate & & & & \\
\hline & & & & & & & & \\
\hline Female & 180 & $(67.2)$ & 88 & $(32.8)$ & & & & \\
\hline Male & 66 & (64.7) & 36 & (35.3) & & & & \\
\hline Age & & & & & 0.343 & 1 & 0.558 & 273 \\
\hline Lower than 20 years & 51 & (63.7) & 29 & (36.3) & & & & \\
\hline 20 years and above & 195 & $(67.2)$ & 95 & $(32.8)$ & & & & \\
\hline $\begin{array}{l}\text { Religion } \\
\text { Islam }\end{array}$ & 195 & (65.2) & 104 & $(34.8)$ & 1.126 & 1 & 0.289 & \\
\hline Buddhism & 51 & (71.8) & 20 & $(28.2)$ & & & & \\
\hline Faculty & & & & & 4.815 & 3 & 0.186 & \\
\hline Humanities and social sciences & 73 & (70.9) & 30 & $(29.1)$ & & & & \\
\hline Education & 56 & (62.2) & 34 & (37.8) & & & & \\
\hline Sciences and technologies & 71 & (71.7) & 28 & (28.3) & & & & \\
\hline Management sciences & 46 & $(59.0)$ & 32 & $(41.0)$ & & & & \\
\hline Year level (year) & & & & & 3.497 & 3 & 0.321 & \\
\hline 1 st & 74 & (65.5) & 39 & $(34.5)$ & & & & \\
\hline 2nd & 69 & (61.6) & 43 & (38.4) & & & & \\
\hline 3rd & 52 & (67.5) & 25 & (32.5) & & & & \\
\hline 4th-5th & 51 & $(75.0)$ & 17 & $(25.0)$ & & & & \\
\hline Residence & & & & & 2.199 & 2 & 0.333 & \\
\hline Own house & 115 & (63.5) & 66 & (36.5) & & & & \\
\hline College dormitory & 65 & (66.3) & 33 & $(33.7)$ & & & & \\
\hline Private dormitory & 66 & (72.5) & 25 & (27.5) & & & & \\
\hline Payment per week (Baht) & & & & & 6.052 & 1 & 0.014 & \\
\hline$\leq 1,000$ & 195 & (63.7) & 111 & (36.3) & & & & \\
\hline$>1,000$ & 51 & (79.7) & 13 & (20.3) & & & & \\
\hline Knowledge level of COVID-19 transmission & & & & & 6.745 & 2 & 0.034 & \\
\hline Good & 102 & (70.8) & 42 & $(29.2)$ & & & & \\
\hline Moderate & 129 & (66.5) & 65 & (33.5) & & & & \\
\hline Poor & 15 & (46.9) & 17 & (53.1) & & & & \\
\hline $\begin{array}{l}\text { Attitude level of the state measures for COVID-19 } \\
\text { prevention and control }\end{array}$ & & & & & 5.722 & 1 & 0.017 & $\begin{array}{l}\text { Association between } \\
\text { factors and social }\end{array}$ \\
\hline High & 203 & (69.5) & 89 & (30.5) & & & & responsibility \\
\hline Moderate & 43 & (55.1) & 35 & (44.9) & & & & behaviors $(n=370)$ \\
\hline
\end{tabular}

\section{References}

1. Zhou F, Yu T, Du R, Fan G, Liu Y, Liu Z, Xiang J, Wang Y, Song B, Gu X, Guan L, Wei Y, Li H, Wu X, Xu J, Tu S, Zhang Y, Chen H, Cao B. Clinical course and risk factors for mortality of adult inpatients with COVID-19 in Wuhan, China: a retrospective cohort study. Lancet. 2020; 395: 1054-62. doi: 10.1016/S0140-6736(20)30566-3.

2. Yang X, Yu Y, Xu J, Shu H, Xia J, Liu H, Wu Y, Zhang L, Yu Z, Fang M, Yu T, Wang Y, Pan S, Zou X, Yuan S, Shang Y. Clinical course and outcomes of critically ill patients with SARS-CoV-2 pneumonia in Wuhan, China: a single-centered, retrospective, observational study. Lancet. 2020; 8: 475-81. doi: 10.1016/S2213-2600(20)30079-5.

3. Huang C, Wang Y, Li X, Ren L, Zhao J, Hu Y, Zhang L, Fan G, Xu J, Gu X, Cheng Z, Yu T, Xia J, Wei Y, Wu W, Xie X, Yin W, Li H, Liu M, Xiao Y, Gao H, Guo L, Xie J, Wang G, jiang R, Gao Z, Jin Q, Wang J, Cao B. Clinical features of patients infected with 2019 novel coronavirus in Wuhan, China. Lancet. 2020; 395: 497-506. doi: 10.1016/S0140-6736(20)30183-5.

4. Chen N, Zhou M, Dong X, Qu J, GongF, Han Y, Qiu Y, Wang J, Liu Y, Wei Y, Xia J, Yu T, Zhang X, Zhang L. Epidemiological and clinical characteristics of 99 cases of 2019 novel coronavirus 
JHR

35,3

pneumonia in Wuhan, China: a descriptive study. Lancet. 2020; 395: 507-13. doi: 10.1016/S01406736(20)30211-7.

5. Narware A. COVID-19: social aspects and responsibilities. ERJ. Soc. Sci. \& Hu. 2020; 2(2): $40-44$.

6. World Health Organization [WHO]. Coronavirus disease (COVID-19) Pandemic: Coronavirus disease (COVID-19) outbreak situation. Geneva: WHO; 2020.

7. The Ministry of Public Health, Department of Disease Control. Corona virus disease (COVID-19): Thailand situation. Thailand: Department; 2020.

8. Yala Province. COVID-19 situation in Yala. [cited 2020 May 12]. Available from: http://www.yala. go.th/covid.

9. Wolf MS, Serper M, Opsasnick L, O'Conor RM, Curtis LM, Benavente JY, Wismer G, Batio S, Eifler M, Zheng P, Russell A, Arvanitis M, Ladner D, Kwasny M, Persell SD, Rowe T, Linder JA, Bailey SC. Awareness, attitudes, and actions related to COVID-19 among adults with chronic conditions at the onset of the U.S. Outbreak. Ann Intern Med. 2020. doi: 10.7326/M20-1239.

10. Bedford J, Enria D, Giesecke J, Heymann DL, Ihekweazu C, Kobinger G, Lane HC, Memish Z, Oh MD, Sall AA, Schuchat A, Ungchusak K, Wieler LH. COVID-19: towards controlling of a pandemic. Lancet. 2020; 395. doi: 10.1016/S0140-6736(20)30673-5.

11. Chin J, Beck D, Deichen M, Huey M, English CH, Jacobs J, et al. Preparing for COVID-19. Silver spring. MD: American College Health Foundation; 2020.

12. Plianbangchang S. Final orientation for new graduates on the highest attainable standard of health. J Health Res. 2019; 33(5): 362-365. doi: 10.1108/JHR-03-2019-0043.

13. Dimopoulos T. COVID-19 outbreak in Greece: current response, personal responsibility and social solidarity; 2020. [cited 2020 May 12]. Available from: https:/healthmanagement.org/24 Mar.

14. Lopez SD, Marin LR, Ruiz SM. Introducing personal social responsibility as a key element to upgrade CSR. Spanish J. Marketing. 2017; 21: 146-163.

15. Bloom BS, editor. Taxonomy of educational objectives. Cognitive domain. New York: McKay; 1956. 1.

16. Ajzen I, FM. Attitude-behavior relations: a theoretical analysis and review of empirical research. Psychol Bull. 1977; 84: 888-918. doi: 10.1037/0033-2909.84.5.888.

17. Education Service. Educational statistics. Yala: Yala Rajabhat University. 2019.

18. Krejcie RV, Morgan DW. Determining sample size for research activities. Educ Psychol Meas. 1970; 30(3): 607-610.

19. Bloom BS. Mastery learning. Evaluation Comment. 1968; 1(2): 1-11.

20. Zhong BL, Luo W, Li HM, Zhang QQ, Liu XG, Li WT, Li Y. Knowledge, attitudes, and practices towards COVID-19 among Chinese residents during the rapid rise period of the COVID-19 outbreak: a quick online cross-sectional survey. Int J Biol Sci 2020; 16(10): 1745-1752.

21. Rodrigues P, Borges AP. Corporate social responsibility and its impact in consumer decisionmaking. Soc Responsib J 2015; 11(4): 690-701. doi: 10.1108/SRJ-02-2014-0026.

22. ŠarotarŽižek S., Mulej M.. Creating a healthy company by occupational health promotion as a part of social responsibility. Kybernetes. 2016; 45(2): 223-243. doi: 10.1108/K-02-2015-0051.

23. Macassa G, Francisco JC, McGrath C. Corporate social responsibility and population health. Health Sci J. 2017; 11(5): 528.

24. Junnual N, Sota C, Chaikoolvatana A. Effectiveness of a smoking cessation program on selfesteem, attitude, perception, and practice regarding control over smoking among male high school. J Health Res. 2019; 33(5): 366-374. doi: 10.1108/JHR-05-2018-0016.

25. Aung PL, Pumpaibool T, Soe TN, Kyaw MP. Knowledge, attitude and practicelevels regarding malaria among people living in the malaria endemic area of Myanmar.J Health Res. 2020; 34(1): 22-30. doi: 10.1108/JHR-01-2019-0012. 
26. Riggin B, Danylchuk K, Gill D, Petrella R. Social impact of a corporate social responsibility initiative. Sports, Bus. Manag2019; 9(4): 344-362. doi: 10.1108/SBM-10-2018-0094.

27. Delautre G, Abriata BD. Corporate social responsibility: exploring determinants and complementarities. Geneva: ILO; 2018.

Corresponding author

Awirut Singkun can be contacted at: awirut@yala.ac.th
Factors associated with social responsibility

For instructions on how to order reprints of this article, please visit our website: www.emeraldgrouppublishing.com/licensing/reprints.htm Or contact us for further details: permissions@emeraldinsight.com 